\title{
Implementation of active learning methods by nurse educators in undergraduate nursing students' programs - a group interview
}

Sanela Pivač ${ }^{\text {** }}$, Brigita Skela-Savič ${ }^{1}$ Duška Jović², Mediha Avdićc and Sedina Kalender-Smajlovićc

\begin{abstract}
Background: Modern and active learning methods form an important part in the education of Nursing students. They encourage the development of communication and critical thinking skills, and ensure the safe health care of patients. Our aim was to obtain naturalistic data from nurse educators regarding want the use and effects of implementing active learning methods (Peyton's Four-Step Approach, Mind Mapping, Debriefing and Objective Structured Clinical Examination methods) in the study process of students of Nursing after a completed education module, Clinical skills of mentors, as part of the Strengthening Nursing in Bosnia and Herzegovina Project. We wish to learn about the perception of nurse educators regarding the use of active learning methods in the study process of Nursing in the future.
\end{abstract}

Methods: Qualitative research was conducted and a group interview technique was used for data collection. Beforehand, research participants were included in a two-day education module, Clinical skills of mentors, as part of the Strengthening Nursing in Bosnia and Herzegovina Project. Content analysis of the discussion transcriptions was conducted.

Results: Fourteen nurse educators participated. Group interviews were conducted in September 2019. The obtained categories form four topics: (1) positive effect on the development of students' communication skills (2) positive effect of learning methods on the development of students' critical thinking skills (3) ensuring a safe learning environment (4) implementation of active learning methods.

Conclusions: The use of various active learning methods in simulation settings improves the Nursing students' critical thinking and communication skills. Therefore, we believe that Peyton's Four-Step Approach, Mind Mapping and Debriefing methods should be included as tools for effective student learning and as preparation for directly performing safe nursing interventions with a patient. Effective approaches to the assessment of Nursing students may ensure quality patient health care in accordance with the vision of the nursing profession.

Keywords: Nursing education, Teaching tools, Critical thinking, Communication skills

\footnotetext{
* Correspondence: spivac@fzab.si

'Angela Boškin Faculty of Health Care, Spodnji Plavž 3, SI-4270 Jesenice,

Slovenia

Full list of author information is available at the end of the article
}

(c) The Author(s). 2021 Open Access This article is licensed under a Creative Commons Attribution 4.0 International License, which permits use, sharing, adaptation, distribution and reproduction in any medium or format, as long as you give appropriate credit to the original author(s) and the source, provide a link to the Creative Commons licence, and indicate if changes were made. The images or other third party material in this article are included in the article's Creative Commons licence, unless indicated otherwise in a credit line to the material. If material is not included in the article's Creative Commons licence and your intended use is not permitted by statutory regulation or exceeds the permitted use, you will need to obtain permission directly from the copyright holder. To view a copy of this licence, visit http://creativecommons.org/licenses/by/4.0/ The Creative Commons Public Domain Dedication waiver (http://creativecommons.org/publicdomain/zero/1.0/) applies to the data made available in this article, unless otherwise stated in a credit line to the data. 


\section{Introduction}

Education of nurses in Bosnia and Herzegovina (BiH) has been undergoing rapid development. In $\mathrm{BiH}$, the emphasis of the health care system and the education of health professionals is mainly on curative care and medical services. This might limit the potential of the nursing staff to react to the population's present and future health needs. To avoid the negative consequences of reduced competencies and practice, nurses developed a project that would strengthen nursing in $\mathrm{BiH}$ [1].

Several nursing-related challenges that currently have a negative effect on the nursing profession and which, therefore, hinder health outcomes in $\mathrm{BiH}$, were identified in collaboration with major stakeholders in $\mathrm{BiH}$, including faculties of nursing and other important organizations [2]. As stated by Francis and O'Brien [3], teaching clinical skills is an important part in educating students of Nursing in an increasingly more complex health care and social environment. As a method of teaching, skills-lab training is viewed as a key component of curricula in the majority of our faculties that offer health-related study programs as it enables a protected training environment where students are permitted to make mistakes and where they can practice their skills on mannequins before working on real patients [4].

In $\mathrm{BiH}$, mentorship at faculties of Nursing is conducted by graduate nurses who are teaching assistants or senior teaching assistants rather than mentors, and are employed full-time or are outsourced. In $\mathrm{BiH}$, there are no additional training options that would equip nurses to work as mentors, either full time or part time, so they only need to meet the general and specific criteria for an associate/teacher position [5]. That is why in 2017, the Strengthening Nursing in BiH Project developed a training program for $\mathrm{BiH}$ clinical skills mentors that comprised seven modules (34 h in total) and was focused on different aspects of adult education, and teaching tools and methods. In $\mathrm{BiH}$, the faculties offering Nursing courses have been faced with challenges regarding the organization of additional training for clinical skills mentors. In order for mentors to be prepared for this role as best as they can, they use professional literature, the internet and engage in team meetings [6].

\section{Background}

In order to improve nursing education, various teaching methods have been introduced to assist students in gaining knowledge, skills and attitudes that are relevant for nursing practice.

The implementation of active learning methods into the study process might result in students' improved motivation for learning, encourage their critical thinking skills and independent learning [7]. Rather than continuing with employing traditional teacher-centered educational approaches, faculties should introduce an active student-centered learning environment since creating learning experiences that encourage reflection, knowledge building, problem-solving, inquiry, and critical thinking are highly significant $[8]$. Authors $[9,10]$ state that active learning methods in nursing education are highly significant with an aim to eliminate passive listening and transition to assuming an active role in the educational process and obtain the ability to apply information from lectures in a meaningful way. The development of the pedagogical skills occurs according to the actual situation in the process of the nurse's practical work [11].

The use of simulation-based learning contributes to the development of students' sense of safety when they perform various tasks [12]. The skill laboratory functions as a transitional setting between a classroom and clinical venues [13].

Peyton's Four-Step Approach is a learning method that comprises four steps and is highly effective in the learning process of nursing interventions. The first step is demonstration, in which the teacher demonstrates the intervention at their normal pace without giving any additional verbal explanations. The second step is deconstruction, in which the teacher performs the intervention by giving detailed descriptions of all the phases of the intervention. In the third step referred to as comprehension, the teacher performs the intervention according to the student's instructions of each step of the intervention. In the final, fourth step called intervention, students perform the intervention by themselves without the help of the teacher [14]. In the research on the effectiveness of the method, the authors found that the Peyton's Four-Step Approach method enables students' active involvement in the process of learning about nursing intervention [15]. The process of self-explanation, which Peyton's Four-Step Approach contains when a student is thinking aloud, enables an improved learning process and the development of critical thinking skills [16].

The Mind Mapping method is an excellent pedagogical tool used to help students achieve positive learning outcomes [17] that may be successfully implemented in the education process as it ensures a creative environment and is an effective tool for teachers, mentors, students and researchers [18]. The Mind Mapping method encourages students to obtain relevant information and develops critical thinking skills, which in turn, has positive effects on the provision of safe health care for patients [19]. There are several reasons why using the Mind Mapping method in learning and teaching is recommended. Firstly, there is no long text. Also, it enables learning through synthesizing, as well as clarification and better reorganization of ideas. Furthermore, it assists 
with revision, encourages visualization of the content that had been learnt before, enables cooperation via studying in groups, which has positive consequences for everybody involved, and finally, mind maps that are submitted to the group result in a better experience because more participants are involved, which produces more ideas and stimulates the use of critical thinking skills [20-22].

The use of simulation-based learning contributes to the development of students' sense of safety when they perform various tasks [12]. The skill laboratory functions as a transitional setting between a classroom and clinical venues [13].

A guided discussion is also quite significant in teaching Nursing students as it enables very authentic simulations of reality since a mentor asks students to critically evaluate their knowledge and skills that they had demonstrated while performing the scenario. Despite much research conducted on educating with simulation, the guided discussion has not yet been sufficiently defined [23]. The use of scenarios with debriefing constitutes a strategy facilitating the teaching-learning process in the undergraduate nursing course [24].

The assessment of clinical skills is also highly significant in nursing education. Therefore, the Objective Structured Clinical Examination (OSCE) may be considered to be a sound assessment tool whose objective is the assessment of nursing students' clinical competences in a safe and controlled environment, which enables simple assessment of the knowledge and performance of clinical skills that are important in nursing practice. Also, the assessment tool may serve to better prepare students for their profession $[25,12]$.

A higher education teacher is one of the key factors for a nursing student to be successful in their studies [26], so teachers should be familiar with effective teaching methods [27]. A teacher's primary task is to ensure a creative environment and a learning path that engages a student [28]. A suitable learning method may encourage nursing students to learn, improve students' communication, and motivate and inform them about effective learning [29].

\section{Aim of the study}

After conducting the educational module Clinical skills of mentors as part of the Strengthening Nursing in $\mathrm{BiH}$ Project, our aim was to obtain naturalistic data from nurse educators regarding the use and effects of introducing active learning methods (Peyton's Four-Step Approach, Mind Mapping, Debriefing and Objective Structured Clinical Examination methods) in the study process of Nursing students. Nurse educators in $\mathrm{BiH}$ have not yet developed knowledge in the field of active and contemporary learning methods or competencies to transition to modern teaching methods from more traditional ones. That is why we conducted the research to learn about the perception of nurse educators about the use of active learning methods in the study process of Nursing in the future.

\section{Our research question was}

What is the perception of nurse educators on the use and effects of active learning methods in nursing undergraduate study programs?

\section{Methods \\ Design}

The qualitative descriptive study of a formal group interview was used [30]. The group interview was conducted in pre-existing "natural" groups of nursing educators in a region of $\mathrm{BiH}$. Invited participants attended a two-day education module: Clinical skills of mentors as part of the Strengthening Nursing in $\mathrm{BiH}$ Project that was hosted by two higher education senior lecturers of Nursing from Slovenia, where higher education and clinical mentorship in Nursing is developed in accordance with international [31,32] and national guidelines for Nursing education [33].

A group interview allows group members to influence each other with their comments and experience, and to form an opinion regarding the issue currently discussed after reflecting on it as a group [34], which results in obtaining more information than with face-to-face interviews [35].

\section{Setting and participants}

The environment in which the research was conducted impacted the format of the group [27] that was invited to participate for research purposes. 14 nurse educators that are employed at the faculty $(n=6)$ and/or in a clinical setting $(n=8)$ participated in a group interview. 12 women and two men participated, the average age of the participants was 35.7 years ( $S D=0.7)$, the average length of service was 15.1 years $(S D=11.1)$. One participant had completed doctoral studies, nine held master's degrees in Nursing and four held bachelor degree in Nursing.

\section{Instrument}

Semi-structured guiding questions that were being updated throughout the discussion were used in the group interview. The semi-structured interview contained eight basic questions:

- What is your opinion regarding the significance of the qualifications of nurse educators to work with Nursing students? 
- What skills should nurse educators have in order to teach students of Nursing effectively?

- How useful do you think the Peyton's Four-Step Approach method is for teaching Nursing students?

- What is your opinion on the usefulness of the OSCE stations as a method of assessing Nursing students?

- How do you assess the usefulness of the Mind Mapping method in the learning process?

- What is your attitude towards using and implementing the Debriefing method in the process?

- Which presented method do you think is most suitable for teaching the students of Nursing?

- What is your attitude towards the impact of the presented learning methods and assessment on the development of critical thinking skills of Nursing students?

The reliability of the research was ensured by considering the homogeneity of the group, an appropriate number of participants in the interview, by giving instructions before the start of the interview emphasizing that everyone has the possibility to participate in the discussion and by encouraging them with questions when guiding the group interview [36]. The reliability check was ensured by digitally recording the conversations in the group interview. We then transcribed the recording and checked that the transcription matched the audio recording. To increase the validity of data analysis, two researchers analyzed the data and ensured that the codes were unified. An independent analysis of two researchers decreases the possibility of partiality and increases the interpretative basis of the research. With the thematic analysis, we demonstrated that data analysis has been conducted in a precise, consistent, and exhaustive manner through recording, systematizing, and disclosing the methods of analysis with enough detail [37]. Also, we used traditional tools: colored pens, paper, and sticky notes for ensuring rigor [38]. Authors checked the participants to ensure relevant evaluation [39].

\section{Data collection}

The group interview took place in September 2019 at the end of the education module and was guided by a moderator and a semi-structured questionnaire. There was also an administrator who recorded the discussions. The research participants attended a two-day education module, Clinical skills of mentors, as part of the Strengthening BiH Project. The purpose of the module was to inform and educate nurse educators about active learning methods and assessment of students of Nursing: Mind Mapping, Debriefing, Peyton's Four-Step Approach methodology and the OSCE stations. We presented the purpose of the research and topics before conducting the group interview. The average time of the group interview was $90 \mathrm{~min}$. Discussions were recorded upon obtaining a written permission by the participants. To ensure anonymity we added randomly selected letters to the interviewers.

\section{Data analysis}

For qualitative data, the method of thematic content analysis was employed. All recordings were transcribed verbatim and the texts were read several times. After coding units were identified, coding was conducted and categories and key topics were defined. Each participant in the group interview was ascribed a corresponding code. The nominal identity of a transcription was lost while the traceability of content was ensured. Authors state that a thematic analysis is a widely used qualitative analytical method that offers an accessible and theoretically adjustable approach to the analysis of qualitative data [40].

\section{Results}

Based on an analysis of the text, 47 codes were designed alongside 14 umbrella categories. The obtained categories fall into four final topics: (1) a positive effect on the development of students' critical thinking skills (2) a positive effect of learning methods on the development of students' critical thinking skills (3) providing a safe learning environment (4) implementation of active learning methods (Table 1).

Table 2 presents topics that are substantiated by representative quotes, their effects on the education of students of nursing, the obstacles and consequences that nurse educators have observed, and suggestions regarding improvements based on the presented topics and statements.

\section{A positive effect on the development of students' communication skills}

Participants in the group interview believed that various active methods have a positive effect on the development of Nursing students' communication skills, and on achieving professional competencies in communication. They emphasize the importance of feedback exchanged between a student and a nurse educator that should be given at a time when a student is still thinking about their work and there is still time to improve the process itself. They think that feedback has an impact on the active role of a student and on achievement of the set goals. The research participants believe that showing nursing interventions several times during the learning process has positive effects on students' memorizing skills and results in less errors when providing health care to patients. 
Table. 1 The results of the discussion on the use of active learning methods in Nursing undergraduate study programs

\begin{tabular}{lll}
\hline Categories & $\begin{array}{c}\text { Number of } \\
\text { codes }\end{array}$ & Topics \\
\hline Communication skills & 5 & Positive effect on the development of students' communication skills \\
Feedback & 4 & \\
Memorizing & 1 & \\
Encouraging critical thinking & 8 & Positive effect of learning methods on the development of students' critical thinking \\
Reflection of students on the issue & 1 & \\
Problem solving & 1 & \\
Active role of students & 3 & \\
Safety & 5 & Ensuring a safe learning environment \\
Significance of learning strategies for & 3 & \\
patients & & \\
Students' perspective & 5 & \\
Learning with simulations & 4 & \\
Assessment approaches & 3 & \\
Usefulness of methods & 2 & Implementation of active learning methods \\
The roles and skills of teachers & 2 & \\
\hline
\end{tabular}

2. The effect of learning methods on the development of critical thinking

In their statements, the participants of the group interview most often stated that using various innovative methods in a simulation setting encourages critical thinking skills of nursing students, impacts the development of students' self-confidence and motivates them to work and study. Active participation and critical thinking lead students to successful problem solving. Participants believe that teaching by means of actively solving problems results in students' reflecting and encourages them to show and say what they know. The participants emphasize that using certain methods of learning also depends on external resources.

\section{Ensuring a safe learning environment}

The participants of the group interview all thought that methods such as the Peyton's Four-Step Approach method, the OSCE stations and Debriefing contribute to a safe clinical environment since students revise their knowledge and skills several times in simulated conditions and in this way strengthen their knowledge. They believe that preparing students to perform safe nursing intervention is connected to safe and quality patient health care in a clinical setting.

\section{Implementation of active learning methods}

The nurse educators included in the research found the presented methods highly suitable for use in the education process of Nursing students, but emphasized that a suitable venue should be provided, and that teachers or clinical mentors should be suitably prepared. They think that nurse educators neither have enough pedagogical and andragogical experiences and skills, nor knowledge on active learning methods.

\section{Discussion}

With qualitative research, we obtained the views and opinions of nurse educators from some nursing faculties and clinical settings in $\mathrm{BiH}$ on the effects of active learning methods on students of nursing. Participants in the group interview believed that various active methods have a positive effect on the development of Nursing students' communication skills, and on achieving professional competencies in communication. They emphasized the importance of feedback exchanged between a student and a nurse educator. Other research [41-43] also emphasizes the importance of communication skills, giving feedback and providing quality in nursing care. In our study the participants of the conducted research thought that active learning methods contribute to a more effective learning of nursing interventions, provide an active approach to learning about nursing interventions and enable a more confident performance of nursing interventions in a clinical setting with a patient, and provide a safe environment either for the patient or for the student.

Participants believe that the use of innovative methods in a simulation environment encourages students' critical thinking, motivation, development of self-confidence and problem-based learning. Christianson Krista [44] puts great importance on the connection between emotional intelligence and critical thinking in nursing education. A study [45] demonstrated that critical thinking education improves problem-solving skills. A good relationship between a nurse educator and a student brings 
Table.2 Effects of active learning methods in Nursing study programs, and suggestions based on the discussion with nurse educators

\begin{tabular}{|c|c|c|c|c|}
\hline Topics & $\begin{array}{l}\text { Selected examples of } \\
\text { comments }\end{array}$ & Effects & $\begin{array}{l}\text { Obstacles } \\
\text { consequences }\end{array}$ & Suggestions \\
\hline $\begin{array}{l}\text { Positive effect on } \\
\text { the development } \\
\text { of students' } \\
\text { communication } \\
\text { skills }\end{array}$ & $\begin{array}{l}\text { "I would like to stress that } \\
\text { communication is very important } \\
\text { between students and mentors... } \\
\text { which means that mentors pass } \\
\text { on their knowledge and } \\
\text { experience through } \\
\text { communication." } \\
\text { (Person K) } \\
\text { "... Communication is very } \\
\text { important and also our thinking, } \\
\text { we should teach our students } \\
\text { through role play." (Person F) } \\
\text { "... with communication we can } \\
\text { solve a problem." (Person I) } \\
\text { "It is important that a student } \\
\text { gets information immediately." } \\
\text { (Person D) } \\
\text { "A teacher's feedback is very } \\
\text { important, so that the student } \\
\text { knows where they were wrong } \\
\text { and what they should do to } \\
\text { improve." (Person B) }\end{array}$ & $\begin{array}{l}\text { Achieving professional } \\
\text { competencies in } \\
\text { communication. } \\
\text { Decreasing errors in patient } \\
\text { care. } \\
\text { Transfer of knowledge and } \\
\text { experiences to students of } \\
\text { Nursing. } \\
\text { The impact of feedback on } \\
\text { the student's active role and } \\
\text { achieving set goals. } \\
\text { Teaching by including active } \\
\text { problem solving that leads } \\
\text { students to reflect and } \\
\text { encourages them to show } \\
\text { and say what they know. } \\
\text { Assessment of the health } \\
\text { condition. } \\
\text { Prevention of errors in a } \\
\text { clinical setting. } \\
\text { Active participation of all } \\
\text { students. }\end{array}$ & $\begin{array}{l}\text { Feedback by nurse educators } \\
\text { should be useful and given } \\
\text { at the right time as, } \\
\text { otherwise, it is not useful. It } \\
\text { should be given when a } \\
\text { student is reflecting on their } \\
\text { work and there is still time } \\
\text { for improvement. } \\
\text { The OSCE method requires } \\
\text { appropriate logistics and } \\
\text { extra support (time, place). }\end{array}$ & $\begin{array}{l}\text { With learning and direct work } \\
\text { a student progresses from an } \\
\text { inexperienced individual to a } \\
\text { more independent, } \\
\text { professional and responsible } \\
\text { person, so strengthening } \\
\text { students' interpersonal } \\
\text { communication competencies } \\
\text { is necessary: communication } \\
\text { skills, a positive and } \\
\text { professional attitude, active } \\
\text { listening, the ability to reflect } \\
\text { and respond emphatically, } \\
\text { constructive feedback that can } \\
\text { be achieved by introducing } \\
\text { active learning methods into } \\
\text { the study process. } \\
\text { Nurse educators should adjust } \\
\text { the teaching methods } \\
\text { depending on the resources, } \\
\text { knowledge, experience of } \\
\text { students and situation. }\end{array}$ \\
\hline
\end{tabular}

Positive effect of "A student should definitely be learning methods on the development of students' critical thinking all the facts that they have proach method." (Person I)
Ensuring a safe learning environment encouraged to think and connect through the Peyton's four-step ap-

"It is great for the development of critical thinking." (Person F)

"It means that they will know what is best for the patient" (Person G)

"With the Debriefing method we will make students think critically and so they will know what they have missed....it is important to have a discussion with students." (Person B)

"Through Mind Mapping students and those students who usually don't speak as much, will participate in discussions." (Person B)

"The disadvantage of the OSCE method is the venue that cannot cater for that many stations, but otherwise, it is a great method for assessment." (Person E)

Implementation of "I'd like to add that teachers active learning should have pedagogical and methods
Development of selfconfidence in students. Students are better motivated.
"The main goal is to ensure the safety of our patients". (Person I) "...the Peyton's four-step approach can also be used for education of patients, which means that it has a large spectrum". (Person K)

Preparation for safe nursing intervention.

Safe and high-quality patient care in a clinical setting.

Standardized methods with precisely defined criteria and andragogical knowledge and skills phases of performing clinical and mentoring skills." (Person J) "During the OSCE exam it is easier to follow two people and that they then make comparisons" (Person Y)

"... that these simulations are interventions.

Improvement of knowledge and clinical interventions. Preparation for work with a patient is very important.
Peyton's four-step approach requires following in steps.

Lack of knowledge of nurse educators on active learning methods.

Nurse educators do not have enough pedagogical and andragogical knowledge.
To ensure a systematic approach to improve the quality and safety of everyone involved.

Strengthening nurse educators with knowledge in pedagogy and andragogy, and active teaching methods. 
Table.2 Effects of active learning methods in Nursing study programs, and suggestions based on the discussion with nurse educators (Continued)

\begin{tabular}{|c|c|c|c|}
\hline Topics & $\begin{array}{l}\text { Selected examples of } \\
\text { comments }\end{array}$ & $\begin{array}{l}\text { Obstacles } \\
\text { consequences }\end{array}$ & Suggestions \\
\hline & $\begin{array}{l}\text { necessary and that in this way we } \\
\text { can prepare students for their } \\
\text { work well, but that for that we } \\
\text { need to have knowledge." (Person } \\
\text { I). } \\
\text { "In my work I will use the OSCE } \\
\text { stations because I think that this } \\
\text { is a good way to check students' } \\
\text { resourcefulness in addition to their } \\
\text { knowledge and skills." (Person C) } \\
\text { "Using the Mind Mapping method } \\
\text { may be the cheapest method and } \\
\text { does not take a lot of time, but is } \\
\text { very effective for the students." } \\
\text { (Person B) }\end{array}$ & & \\
\hline
\end{tabular}

positive results in students' education and motivates them for work in a clinical setting [46]. In addition, a teacher's professional knowledge and their organizational and communication skills also have an effect on successful learning [47]. Baksi et al. [48] researched the effects that clinical preparatory education provided before the first clinical experience had on anxiety.

The opinions of the participants regarding the Debriefing method mostly refer to the importance of feedback. In researching debriefing practices in interprofessional simulation with students from the sociomaterial perspective, the findings have shown how debriefing intertwines with, and is shaped by social and material relationships. Two patterns of enacting debriefing were identified. First, debriefing as an algorithm was enacted as a protocol-based, closed inquiry approach and secondly, laissez-faire debriefing was enacted as a collegial conversation with an open inquiry approach that has a loose structure [49].

Nursing educators believe that active pedagogical methods of learning might help students to optimize the development of their critical thinking skills. Therefore, we believe that Peyton's Four-Step Approach method, Mind Mapping and Debriefing should be included as a tool for successful learning of students and preparation for working directly with patients, which has already been pointed out by previous research conducted by Janicas and Narchi [24] and Francis and O'Brien [3].

The use of Mind Mapping helps students to understand their thinking process, obtain basic knowledge that they will upgrade with in-depth professional knowledge [18], and encourages them to learn independently, be independent and think critically [50]. While students were developing mind maps, they were also exploring the critical thinking concept by reflecting on how they make patient care decisions in a clinical setting [22]. The reflection resulted in the students being better able to describe their critical thinking process and demonstrate the concept graphically. Mind Mapping may be used to illustrate the pathways that encourage reflection on patient care [51].

The participants of our research believe that the methods that were presented and demonstrated with examples contribute to a safe clinical setting. Clark [25] also emphasizes that one of the more challenging tasks of faculties of health sciences is to educate students with competencies that will secure safe and effective nursing and patient care. In the research, nurse educators believe that active methods are very useful in the education process of Nursing students, but emphasize that an appropriate location should be provided and that nurse educators should be suitably trained. They also believe that nurse educators must have pedagogical and andragogical knowledge, so that they can implement active and quality teaching methods in the pedagogical process. The challenges in the training of nursing educators are in the transition from traditional education to simulated learning environment [52]. Addressing nurse educator challenges and empowering them with the means, opportunity and skills to utilize student-centered teaching and learning strategies may contribute to the development of undergraduate student nurses' clinical reasoning skills. Raising awareness of the challenges that nurse educators experience in implementing studentcentered facilitation of learning can assist in developing the strategies to ensure nurse educators become more student-centered in their teaching [53].

Based on the conducted research, we propose an implementation of active teaching methods in the educational process of nursing students. Recommendations relate to regular monitoring of learning objectives, evaluation, updating teaching methods and the transition from traditional forms of learning to innovative forms. 


\section{Limitations and Strengths}

Nurse educators that had previously been included in the training on active teaching methods in Nursing were included in the research. An advantage of the research is that we have obtained the views and opinions of nurse educators regarding the usefulness and effectiveness of the presented methods in the undergraduate study program of Nursing immediately after the conducted theoretical and practical training. An important limitation is also the local context of nursing development in $\mathrm{BiH}$. The convenient sampling does not always allow us to select the best representatives related to the research question. It is likely that the members included in the group are more motivated for improvements in nursing education than other nurses at faculties and clinical settings.

Further research should focus on two areas. Firstly, it should be researched how often active learning methods are used in the education process and secondly, the opinions of students on how active learning methods impact the understanding and learning of nursing intervention could be obtained. The limitation of the research is the time span of the education on active teaching methods and the selection of guiding questions, since we are aware that the selection of questions might partially impact the answers given by the participants. It may be supposed that a different selection of guiding questions might result in different opinions of nurse educators.

\section{Conclusions}

The results of the qualitative research were used to present the meaning and understanding of implementing active learning methods in undergraduate study programs of Nursing. Based on the conducted research we believe that nurse educators lack pedagogical and andragogical knowledge as well as knowledge of active learning methods. The use of active learning methods by nurse educators improves communication skills and develop students' critical thinking skills. The final results of implementing active learning methods are in the acquired learning outcomes, nursing interventions that are performed optimally, development of competent professionals, boosting self-confidence, improvement of communication and critical thinking skills, as well as the self-initiative and readiness to work with patients in a clinical setting. Cutting edge and active learning methods are important for ensuring the quality of a study process and in the teaching of students of Nursing. We also wish to encourage study programs where the presented learning methods would be used in the study process, so that students will become active participants who can use their knowledge in providing safe patient care as a result of these active methods of teaching and learning.
We considered ethical principles of ensuring the voluntary nature of participating in the research, protecting the identity of individuals, confidentiality, privacy and respecting the truth. Research was carried out in accordance with the Helsinki-Tokyo Declaration [54], the Code of Ethics for Nurses and Nurse Assistants of Slovenia [55] and the ethical guidelines of the Social Research Ethics Guidance [56, 57]. We did not apply for the approval by the National Medical Ethics Committee as the National Medical Ethics Committee only makes decisions concerning experimental research and nonexperimental research conducted on patients and vulnerable groups in the population (patients, the elderly, children, disabled adults). Nurse educators do not form part of vulnerable groups and our questions were not considered to belong to the group of vulnerable questions. The study is exempt from ethical approval according national legislation (European Commission: Accession countries - legislation related to research ethics Slovenia).

\section{Abbreviations}

BiH: Bosnia and Herzegovina; OSCE: Objective Structured Clinical Examination

\begin{abstract}
Acknowledgements
We would like to thank the Strengthening Nursing in BiH Project for inviting us to participate in the provision of training as a part of the education module: Clinical skills of mentors that enabled us to conduct the research among the training participants after completing the training. We would also like to thank all the participants of the research, who shared their opinions and views about the presented issue.
\end{abstract}

\section{Authors' contributions}

SP contributed to the conception and design of the study, definition of sample, theoretical introduction and discussion, acquisition of data, analysis and interpretation of data. BSS contributed to the design of the study, theoretical introduction, methods, final reading of article. DJ contributed to the theoretical introduction and discussion and acquisition of data. MA contributed to the theoretical introduction and discussion and acquisition of data. SKS contributed to the theoretical introduction, analysis and interpretation of data discussion and conclusions. All authors drafted the manuscript and approved of the final version of the manuscript.

\section{Funding}

This research did not receive any specific grant from funding agencies in the public, commercial, or not-for-profit sectors.

\section{Availability of data and materials}

The datasets used and/or analyzed during the current study are available from the corresponding author on reasonable request.

\section{Declarations}

Ethics approval and consent to participate

In order to conduct the research, we received a written consent from all the research participants. We ensured the anonymity of all the research participants. Informed consent was obtained. The participants received information about different aspects of the study; their rights on voluntary participation and withdrawal from the study at any time as well as their privacy and confidentiality rights were explained to them. Permission to conduct the study was obtained from the Senate Committee for Science, Research and Development at the Angela Boškin Faculty of Health Care in August 2019. We obtained the consent from the Fami Foundation for improving Health Care and Social Welfare. 


\section{Consent for publication}

Not Applicable.

\section{Competing interests}

The authors declare that they have no competing interests.

\section{Author details}

'Angela Boškin Faculty of Health Care, Spodnji Plavž 3, Sl-4270 Jesenice, Slovenia. ${ }^{2}$ Faculty of Medicine, Department of Health Care, University of Banja Luka, Banja Luka, Bosnia and Herzegovina. ${ }^{3}$ Public Institution Health Centre of Sarajevo Canton, Sarajevo, Bosnia and Herzegovina.

Received: 27 May 2021 Accepted: 28 August 2021

Published online: 18 September 2021

\section{References}

1. Avdić M, Jović D, Dropić E, Van Malderen, Schwendimann R. Formal education of medical nurses in Bosnia and Herzegovina. Nursing Journal. 2014;1:25-27.

2. Strengthening Nursing in Bosnia and Hercegovina Project, n. d. http://www fondacijafami.org/Sestrinstvo_pdf_/Project\%20Leaflet.pdf. Accessed 15 Jan 2020.

3. Francis $\mathrm{G}, \mathrm{O}^{\prime}$ Brien $\mathrm{M}$. Teaching clinical skills in pre-registration nurse education: value and methods. Br J Nurs. 2019;28:452-6.

4. Awad SA, Mohamed MHN. Effectiveness of Peyton's Four-Step Approach on nursing students' performance in skill-lab training. J Nurs Educ Pract. 2019;5: $1-5$.

5. Jović D, Avdić M, Katić-Vrdoljak I. Assessment of the needs for additional training for clinical skills mentors at the faculties with nursing studies in $\mathrm{BiH}$. In: Pesjak K, Pivač S, editors. Inter-professional integration at different levels of healthcare: trends, needs and challenges. 11th International Scientific Conference, Bled, Slovenia, June 7th, 2018. Jesenice: Angela Boškin Faculty of Health Care; 2018. p. $83-8$.

6. Jović D, Avdić M, Marković N, Katić-Vrdoljak I. Training scheme for clinical skills mentors in Bosnia and Herzegovina. In: Pesjak K, Mlakar S, editors. Responsibilities of health policy-makers and managers for the retention and development of nurses and other healthcare professionals - 2020: International year of the nurse and the midwife. 13th International Scientific Conference, Jesenice, Slovenia, September 24th, 2020. Jesenice: Angela Boškin Faculty of Health Care; 2020. p. 174-8.

7. Parikh ND. Effectiveness of teaching through mind mapping technique. Int J Indian Psychol. 2016;3:148-56.

8. Alexander BJ, Lindow LE, Schock MD. Measuring the impact of cooperative learning exercises on student perception of peerto - peer learning: a case study. J Physican Assist Educ. 2008;3:18-25.

9. Bristol T, Hagler D, McMillian-Bohler J, Wermers R, Hatch D, Oermann MH. Nurse educators' use of lecture and active learning. Teach Learn Nurs. 2019; 14:94-96.

10. Waldeck JN, Weimer M. Sound decision making about the lecture's role in the college classroom. Commun Educ. 2017; doi: https://doi.org/10.1080/03 634523.2016.1275721.

11. Benner $P$, Sutphen $M$, Leonard V, Day L. Educating nurses: a call for radical transformation. San Francisco: Jossey-Bass; 2010.

12. Smrekar M, Ledinski Fičko S, Hošnjak AM, llić B. Use of the objective structured clinical examination in undergraduate nursing education. Croat Nurs J. 2017;1:91-102.

13. Hashim R, Qamar K, Khan MA, Rehman S. Role of skill laboratory training in medical education: students' perspective. J Coll Physicians Surg Pak. 2016;3: 195-8.

14. Nikendei C, Huber J, Stiepak J, Huhn D, Lauter J, Herzog W, et al. Modification of Peyton's Four-Step Approach for small group teaching - a descriptive study. BMC Med Educ. 2014;14:1-8.

15. Ahmed FR, Morsi SR, Mostafa HM. Effect of Peyton's Four Step Approach on skill acquisition, self-confidence and self - satisfaction among critical care nursing students. IOSR-JNHS. 2018;6:38-47.

16. Krauter M, Weyrich $\mathrm{P}$, Schultz JH, Buss SJ, Nikendei C, Junger J, et al. Effects of Peyton's Four-Step Approach on objective performance measures in technical skills training: a controlled trial. Teach Learn Med. 2011:3:244-50.

17. Kernan WD, Basch $\mathrm{CH}$, Carodett V. Using mind mapping to indentify reserach topics: a llesson for teaching research methods. Pedagogy Health Promot. 2017; doi: https://doi.org/10.1177/2373379917719729.
18. Buran A, Filyukov A. Mind mapping tehnique in language learning. Procedia Soc Behav Sci. 2015:206:215-8

19. Noonan M. Mind maps: enhancing midwifery education. Nurse Educ Today. 2013;8:847-52

20. D'Antoni AV, Zipp GP, Olson VG, Cahill TF. Does the mind map learning strategy facilitate information retrieval and critical thinking in medical students? BMC Med Educ. 2010; doi: https://doi.org/10.1186/1472-6920-10-61.

21. Vilela W, Pereira Barbosa LC, Miranda Vilela AL, Santos Neto LL. The use of mind maps as support in medical education. J Contemp Med Edu. 2013;4: 199-206.

22. Rosciano A. The effectiveness of mind mapping as an active learning strategy among associate degree nursing students. Teach Learn Nurs. 2015; 2:93-9.

23. Karnjuš I, Križmarić M, Zazula D. Importance of debriefing in high-fidelity simulations. Slov Med J. 2014:3:246-54.

24. Vieira Janicas RCS, Zanon Narchi N. Evaluation of nursing students' learning using realistic scenarios with and without debriefing. Rev Lat Am Enfermagem. 2019;27:e3187.

25. Clark CA. Evaluating nurse practitioner students through objective structured clinical examination. Nurs Educ Perspect. 2015;1:53-4.

26. Hermansyah D, Witansa R. Influence of use of mind mapping method by teachers on teaching preparation in basic school in subject of materials teaching eyes lesson science natural science (IPA). Journal Elementary Educ. 2017;1:37-52.

27. Lloyd D, Boyd B, Den Exter K. Mind mapping as an interactive tool for engaging complex geographical issuess. New Zealand Geographer Society. 2010; doi: https://doi.org/10.1111/j.1745-7939.2010.01185.x.

28. Zipp GP, Maher C, D'Antoni AV. Mind mapping: teaching and learning strategy for physical therapy curricula. J Phys Ther Educ. 2015;1:43-8.

29. Luo J. Teaching mode of thinking development learning based on mind mapping in the course of health fitness education. iJET. 2019;8:192-205.

30. Green J, Thorogood N. Qualitative methods for health research. London, New Delhi: Sage Publications; 2004

31. European Union. Directive 2005/36/EC of the European Parliament and of the Council. 2005. http://eur-lex.europa.eu/LexUriServ/LexUriServ.do? uri = OJ:L:2005:255:0022:0142:en:PDF. Accessed 17 Jul 2013.

32. European Union. Directive 2013/55/EU of the European Parlament of the Council. 2013. https://eur-lex.europa.eu/LexUriServ/LexUriServ.do?uri=OJ:L: 2013:354:0132:0170:en:PDF. Accessed 9 Jan 2016

33. Skela-Savič B. Smernice za izobraževanje $v$ zdravstveni negi na študijskem programu prve stopnje Zdravstvene nege (VS). Obzor Zdrav Neg. 2015;4: 320-33.

34. Clarke A. Focus group interviews in health-care research. Prof Nurs. 1999;14: 395-7.

35. Bolderston A. Conducting a research interview. J Med Imaging Radiat Sci. 2012;43:66-76

36. Polgar S, Thomas SA. Introduction to research in the health sciences. 4th ed Oxford: Churchill Livingstone: 2000.

37. Nowell LS, Norris JM, White DE, Moules NJ. Thematic analysis: striving to meet the trustworthiness criteria. Int J Qual Methods. 2017;16:1-13.

38. Maher C, Hadfield M, Hutchings $M$, de Eyto $A$. Ensuring rigor in qualitative data analysis: a design research approach to coding combining NVivo with traditional material methods. Int J Qual Methods. 2018; doi: https://doi.org/1 $0.1177 / 1609406918786362$

39. Guba EG, Lincoln YS. Effective evaluation: improving the usefulness of evaluation results through responsive and naturalistic approaches. San Francisco: Jossey-Bass; 1981.

40. Braun V, Clarke V. Using thematic analysis in psychology. Qual Res Psychol. 2006:3:77-101.

41. Hardavella G, Aamli-Gaagnat A, Saad N, Rousalova I, Sreter KB. How to give and receive feedback effectively. Breathe. 2017; doi: https://doi.org/10.11 $83 / 20734735.009917$

42. Ratna $\mathrm{H}$. The importance of effective communication in healthcare practice. Harvard Public Health Review. 2019;23.

43. Bodys-Cupak I, Łatka J, Ziarko E, Majda A, Zalewska-Puchała J. Medical simulation with simulated patients in the education of Polish nursing students - pilot study. Polish Nurs. 2020;3:166-73.

44. Christianson $\mathrm{KL}$. Emotional intelligence and critical thinking in nursing students: integrative review of literature. Nurse Educ. 2020;6:E62-E65.

45. Kanbay $Y$, Okanlı $A$. The effect of critical thinking education on nursing students' problem-solving skills. Contemp Nurse. 2017;3:313-21. 
46. Haakma I, Janssen M, Minnaert A. Understanding the relationship between teacher behavior and motivation in students with acquired deafblindness. Am Ann Deaf. 2016;161:314-26.

47. Al Naqbi $\mathrm{S}$. The use of mind mapping to develop writing skills in UAE schools. Education, Business and Society: Contemporary Middle Eastern Issues. 2011;2:120-33.

48. Baksi A, Gumus F, Zengin L. Effectiveness of the preparatory clinical education on nursing students anxiety: a randomized controlled trial. Int J Caring Sci. 2017;2:1003-12.

49. Nyström S, Dahlberg J, Edelbring S, Hult H, Dahlgren MA. Debriefing practices in interprofessional simulation with students: a sociomaterial perspective. BMC Med Educ. 2016; doi:https://doi.org/10.1186/s12909-0160666-5.

50. Kalyanasundaram M, Abraham SB, Ramachandran D, Jayaseelan JB, Singh Z, Purty AJ. Effectiveness of mind mapping technique in information retrieval among medical college students in Puducherry - apilot study. Indian J Community Med. 2017;19:19-23.

51. Picton C. Mind maps: reflecting on nature. Emerg Nurse. 2009; doi: https:// doi.org/10.7748/en.17.2.3.s1.

52. Lillekroken D. A privilege but also a challenge." Nurse educators' perceptions about teaching fundamental care in a simulated learning environment: A qualitative study. J Clin Nurs. 2020;11/12: 2011-22.

53. van Wyngaarden $A$, Leech $R$, Coetzee I. Challenges nurse educators experience with development of student nurses' clinical reasoning skills. Nurse Educ Pract. 2019; doi: https://doi.org/10.1016/j.nepr.2019.102623.

54. World Medical Association. https://www.wma.net/policies-post/wma-declara tion-of-helsinki-ethical-principles-for-medical-research-involving-humansubjects/ 2013. Accessed 12 Feb 2020.

55. Kodeks etike $v$ zdravstveni negi in oskrbi Slovenije. 2014. http://www.kmenmec.si/files/2018/03/Kodeks-etike-v-zdravstveni-negi-in-oskrbi-Slovenije-ma rec-2014.pdf. Accessed 12 Feb 2020.

56. Social Resarch Association Research Ethics Guidance. 2003. ethical guidelines 2003.pdf (the-sra.org.uk). Accessed 12 May 2019.

57. Social Resarch Association Research Ethics Guidance. 2021. https://the-sra. org.uk/common/Uploaded\%20files/Resources/SRA\%20Research\%20Ethics\%2 Oguidance\%202021.pdf. Accessed 14 Jun 2021.

\section{Publisher's Note}

Springer Nature remains neutral with regard to jurisdictional claims in published maps and institutional affiliations.

Ready to submit your research? Choose BMC and benefit from:

- fast, convenient online submission

- thorough peer review by experienced researchers in your field

- rapid publication on acceptance

- support for research data, including large and complex data types

- gold Open Access which fosters wider collaboration and increased citations

- maximum visibility for your research: over $100 \mathrm{M}$ website views per year

At $\mathrm{BMC}$, research is always in progress.

Learn more biomedcentral.com/submissions 